variations in the intensity of these solar currents may be followed by a disturbance in the terrestrial magnetism at any time, yet such disturbance should be at a maximum at the equinoxes (as is the case by Secchi's law), because then the sun is most favourably situated for causing such effects.

In this hypothesis the source of the earth's permanent mag. netism is not included, but simply the cause of the close connection between solar eruption and the disturbance of the terrestrial magnetic elements.

F. A. Freming

\section{Mechanism of Flexion and Extension in Birds' Wings}

UNDR the above heading in your issue of January 18,1872 , Dr. Elliot Coues deccribes the feculiar movements made by the bones of the wing of the bird in flexion and extension. It may interest some of your readers to know that those movements were minutely described and elaborately illustrated in a paper by Dr. $J$. Bell Pettigrew, communicated to the Linnean Society in June i 867 , and published in vol. xxvi. of the Transactions of that boriy.

Ldinburgh University, Jan. 22

\section{Elisée Recius}

A MEMORIal addressed to the "Commission des grâces," sitting at Versailles, and most infuentially signed by many of the leading scientific men in London, was presented at Versailles on the 3 rd inst.

It is an appeal for commutation of sentence of deportation passed on Elisée Reclus, the well-known French geographer, author of "La Terre," an admirable popular work on physical geography (now being introduced as an English work * by Alessrs. Crapman and Hally, and various other books.

A paragraph having appeared in several of the daily papers amouncing that $\mathrm{M}$. Reclus's sentence had been already commuted to simple banishment, I regret to state that he is still a prisoner at Versailles, allhough it is hoped the appeals made in his favour may produce the desired result.

The petition to the Commission in favour of Elisée Reclus was signed by the president of the Geological Society (Mr. Prcstuich), Sir Charles Lyell, Bart., Mr. G. Poulett Scrope, Profs. Owen, Ramsay, Williamson, Duncan, Atkinson, Morris, Rupert Jones, Temnant, Messrs. Evans, Forbes, Gwyn Jeffreys, Drs. Carpenter, Richardson, and many others.

A secord petition signed by Sir Henry Rawlinson, Sir John Lubbock, Bart, Mr. Darwin, and other men of eminence, was addressed to M. Thiers in favour of Elisée Reclus.

Surely the time for an amnesty has arrived.

British Museum, January 23

H. WOODWARD

\section{NOTES ON MICROSCOPY}

MOUNTING IN GLYCERINE.- It is often found desirable to mount very thin objects in glycerine, for which no special cell is requisite, and in which the thickness of a cell would be a disadvantage. To accomplish this was often a work of difficulty, since the presence of the smallest amount of glycerine outside the thin glass cover prevented the adhesion of the luting by means of which the cover was to be secured to the slide. Since the introduction of gum dammar dissolved in benzole to the attention of microscopists, this disadvantage has almost wholly vanished. It is now comparatively easy to mount such objects in the following manner. A small drop of glycerine, just enough for the purpose, is let fall in the centre of an ordinary cleaned slide, the object is then placed in the glycerine, having been previously soaked in benzole if any difficulty was likely to be experienced on account of contained air ; a cover (say threc quarters square) of thin glass is placed over the object and pressed down, taking care that the object remains in the centre; a wire clip then applied holds the cover in its place. If too much glycerine has been used, blotting-paper or a camel-hair pencil will remove all that issues beyond the edge of the cover. If too little, the

* Sections I. and II. of this work are already published; Sections III. and IV. are now in the press. addition of more at one edge will supply the deficiency, and the superfiuous remainder may be wiped away. Thus secured by the clip the edges of the cover may be painted round with gum dammar in benzole, and when dry and firm (in a day or two) the clip may be removed, and the surface of the slide carefully washed to remove any trace of glycerine. The clip may be replaced, and a second thin coating of dammar laid over the first, or old gold size may be used instead. When this is dry "papering" the slide in the usual way helps to provide against accident. The advantages derived from the use of this method are chiefly the facility with which the cover is attached, notwithstanding the presence of a trace of glycerine on the slide and cover, which it is not easy to avoid; and, so far as the experience of two years can vouch, freedom from leakage afterwards, especially when covered with paper. This plan succeeds best with objects as thin as the minute spores of fungi, delicate hairs, \&c., and $a$ one-eighth objective may be employed in their examination.

THE ASCI IN PEZIZA.-Having left a specimen of Peziza humosa for a long time in water until it became quite soft and pulpy, I was curious to examine it in such condition, and found that the hymenium presented a singular appearance. All the paraphyses had become dissolved into a granular mass, retaining still some of their original colour. Amongst these the asci were free, and there were some free sporidia. In their normal condition the asci are cylindrical, and the sporidia are arranged in a single series, but in the present case the asci had become perfectly spherical, from the absence of all lateral pressure, and the sporidia were clustered in the centre. The line of the external surface of the asci was very distinct amongst the orange-tinted granular mass, and the eight sporidia could be counted within. There could be no doubt of the presence of an investing membrane, but of a much more elastic nature than has been supposed. This fact seems to suggest the probability that more or less lateral compression in the hymenium may influence the character of the asci, and that cylindrical, or clavate and elliptical asci, indicate more or less of lateral pressure during development.

SACRED THREAD.- The sacred thread, or at least one kind of thread held sacred to religious purposes by the Brahmins in India, is derived from the stem of a species of water lily-some say the Nelumbium speciosum, others Nymphad edulis. At any rate under the microscope it exhibits a mass of spirals, unwinding in ribbons of four or five threads laterally united. 'There is no trace of cells mixed up with it, and the spiral threads are as clean as if they had been removed with special care for microscopical purposes.

HOP MOULD.-A new mould has made its appearance during the past autumn on the spent hops so common about Burton-on-Trent. It formed large dense patches of a bright salmon colour, sometimes several inches in length and breadth, upon the sombre hops, and could not have escaped notice had it appeared in previous years. The structure of this mould seems to be closely allied to that of Oidium, whilst in many respects it reminds one of Sporendonema casei. The creeping mycelium gives rise to branched threads, which become divided into strings of oval conidia or spores. The mould refuses to develop itself artificially, so that the mode in which the beaded spores were produced was not absolutely determined. Directly the threads come in contact with fluid of any kind they are resolved into a mass of oval cells or spores. Specimens of this mould have beer published and distributed in Cooke's "Fifth Century of British Fungi" under the name of Oidium aurantzum, a rather unfortunate specific name, since another member of the same genus which appeared nearly simultaneously on the Continent has been called Oidium aurantiacum.

M. C. C. 